\title{
Chemical Composition, Functional and Sensory Properties of Maize Ogi Fortified with Periwinkle Meat Flour
}

\author{
Ufot Evanson Inyang*, Winifred Edet Effiong \\ Department of Food Science and Technology, University of Uyo, Uyo Akwa Ibom State, Nigeria
}

Email address:

inyang.ufot@yahoo.com (U. E. Inyang)

*Corresponding author

\section{To cite this article:}

Ufot Evanson Inyang, Winifred Edet Effiong. Chemical Composition, Functional and Sensory Properties of Maize Ogi Fortified with Periwinkle Meat Flour. International Journal of Nutrition and Food Sciences. Vol. 5, No. 3, 2016, pp. 195-200.

doi: $10.11648 /$ j.ijnfs.20160503.17

Received: April 9, 2016; Accepted: April 20, 2016; Published: May 3, 2016

\begin{abstract}
The present study was aimed at assessing the effect of supplementing dried maize ogi with 0,5,10,15 and $20 \%$ periwinkle meat flour on the chemical composition and functional properties of the flour blends as well as the sensory properties of the ogi gruel. The result showed that substituting maize ogi with levels of periwinkle meat flour led to significant $(\mathrm{p}<0.05)$ increases in crude protein and ash contents ranging from $7.85 \%$ and $0.81 \%$ in unfortified maize ogi to $14.91 \%$ and $2.17 \%$ in $20 \%$ periwinkle meat flour supplemented ogi, respectively. The crude lipid, crude fibre, carbohydrate and caloric value on the other hand consistently decreased with increasing levels of periwinkle meat flour substitution. The decreases in crude lipid and crude fibre contents were however not significantly $(\mathrm{p}>0.05)$ difference from each other. Potassium and magnesium contents significantly $(\mathrm{p}<0.05)$ decreased with increasing levels of periwinkle meat flour supplementation. Calcium, sodium, iron and zinc on the other hand consistently increased with increasing levels of periwinkle meat flour supplementation. Bulk density, water absorption and swelling capacities consistently decreased while oil absorption and foaming capacities increased with increasing levels of periwinkle meat flour substitution. Result of sensory evaluation indicates that fortification of maize ogi with up to $10 \%$ periwinkle meat flour did not affect the acceptability of the prepared gruel as there was no significant different $(\mathrm{p}<0.05)$ with the gruel from $100 \%$ maize ogi.
\end{abstract}

Keywords: Maize Ogi, Periwinkle Meat Flour, Fortification, Physico-Chemical Properties, Sensory Properties

\section{Introduction}

In most developing countries of the world and particularly in Africa with high poverty level, traditional weaning foods are based on local starchy staples [1]. These foods are high in carbohydrate, but low in protein content. This situation denies the infant and children a balanced diet which is necessary for the maintenance of good health. The implication of feeding children with such food is the incidence of protein-energy-malnutrition, a major cause of high infant morbidity and mortality $[1,2,3]$. Many children are under weight, short or thin as a result of nutritional inadequacy which prevents growth to their genetic potentials.

Ogi is a fermented cereal gruel made from fermented maize (Zea mays), sorghum (Sorghum vulgare) or millet (Pennisetum typodenum) $[4,5]$. It is produced by soaking the cereal of choice in water for 2 - 3 days, followed by wet milling and sieving through a mesh screen. The sediment (ogi) is often marketed as a wet cake wrapped in leaves or transparent polyethylene bags. Gelatinize ogi gruel locally known as "pap" is a popular food used as traditional infant weaning food as well as breakfast meal for many adults in Nigeria [6]. Protein in ogi is much poorer than that of whole cereal because of processing losses [7]. The result is that children fed ogi do not receive enough essential amino acids to meet their body needs for growth and resistance to disease. Attempts have been made to improve the nutritional value of ogi by fortifying it with high protein plant products such as soybean flour [8], tempe [1] and pumpkin seed flour with fish meal $[7,8]$ among others. One major limitation of plant food blends is poor digestibility which has been attributed to low solubility of plant protein [9]. It is hope that the incorporation of low-priced animal product such as 
periwinkle meat flour will improve the quantity and quality of protein in the blends.

Periwinkle (Tympanotonus fuscatus var radula) is a relatively cheap source of animal protein and some mineral element including potassium, calcium, magnesium, sodium, iron and copper $[10,11]$. They are invertebrates and belong to the phylum mollusea. Periwinkle meat is mostly consumed in Niger Delta region of Nigeria and some riverine areas of West Africa [11]. Periwinkle meat in Akwa Ibom State of Nigeria is consumed by both the rich and poor people. Many low income families depend on periwinkle meat as their main source of protein because of their cheapness and availability all year round. Ogungbenle and Omowole [11] reported that the meat contains balanced essential amino acid highly suitable for the fortification of maize food products which are widely used as weaning food for children in most African countries. Its use in culinary preparation is however restricted to the fresh meat with very limited shelf-life. Processing the meat into flour will lead to the extension of the shelf-life, value addition and may increase its utilization potentials in food product formulation and development. The present study was aimed at evaluating the effect of fortifying dried maize ogi with periwinkle meat flour on the physicochemical quality of the blends and sensory quality of the gruels.

\section{Materials and Methods}

\subsection{Sample Collection}

White variety of maize (Zea mays) grains was purchased from Akpan Andem market in Uyo Metropolis of Akwa Ibom State, Nigeria. Periwinkles (spiky species) were purchased from Oron market in Akwa Ibom State, Nigeria.

\subsection{Preparation of Dried Maize Ogi}

The maize grains were cleaned by washing thoroughly with potable water. The grains were soaked in water $(1: 5 \mathrm{w} / \mathrm{v})$ for 48 hours at room temperature $\left(27 \pm 2^{\circ} \mathrm{C}\right)$, decanted and washed with fresh water. The soaked grains were then wet milled using locally fabricated grinder. The slurry was washed through a fine sieve $(200 \mu \mathrm{m})$ with excess water, allowed to settle for 3 hours and the wash water decanted. The sediment was transferred to a clean cheese cloth and squeezed to remove excess water, followed by drying at $60^{\circ} \mathrm{C}$ for 20 hours in a conventional air oven (model PP 22 US, Genlab, England), milled, sieved to pass through $200 \mu \mathrm{m}$ mesh screen, packaged and stored at $4^{\circ} \mathrm{C}$ until used.

\subsection{Preparation of Periwinkle Meat Flour}

Spiky species of fresh periwinkle (Tympanotonus fuscatus) were thoroughly washed with potable water, scrubbed to remove the adhering debris and rinsed. The washed periwinkles were soaked in water $(1: 5 \mathrm{w} / \mathrm{v})$ for 12 hours at room temperature $\left(27 \pm 2^{\circ} \mathrm{C}\right)$, drained, poured into already boiled water $\left(100^{\circ} \mathrm{C}\right)$ and left for $5 \mathrm{~min}$, drained and cooled. Meats were manually removed from the shells with the aid of a sterile needle. The shells were discarded while the meats were washed in potable water, drained, dried at $60^{\circ} \mathrm{C}$ for 20 hours in a conventional air oven (model PP 22 US, Genlab, England), milled into flour using manual grinder, packaged in air-tight plastic container and stored at $4^{\circ} \mathrm{C}$ until used.

\subsection{Substitution Levels of Ogi with Periwinkle Meat Flour}

The maize ogi to periwinkle meat flour ratios used in this study were $100: 00,95: 05,90: 10 ; 85: 15$ and 80:20. The 100\% maize ogi served as the control sample. Each blend was thoroughly mixed in a warring blender to have a homogenous mixture, packaged in air tight plastic container, labeled and stored at $4^{\circ} \mathrm{C}$ until used.

\subsection{Methods of Analysis}

Standard methods of analysis as described in AOAC [12] were used for the determination of crude protein, crude lipid, ash and crude fibre contents. Carbohydrate was determined by difference [13]. Caloric value was calculated using Atwater factor formula as described by Osborne and Voogt [14].

Mineral elements ( $\mathrm{K}, \mathrm{Ca}, \mathrm{Na}, \mathrm{Mg}, \mathrm{Fe}$ and $\mathrm{Zn}$ ) were determined using atomic absorption spectrophotometer (UNICAM Model 939, UK) as described in AOAC [12].

Water absorption, oil absorption and swelling capacities were determined following the methods described by Okezie and Bello [15]. Bulk density and foaming capacity were determined following the methods described by Abbey and Ibeh [16]. The method described by Sathe et al. [17] was employed in the determination of the least gelation capacity.

Sensory evaluation of the gelatinized ogi gruel locally known as "pap" was done on the coded samples by a twenty member semi-trained panel drawn from the University of Uyo community. The attributes evaluated were appearance, taste, consistency and overall acceptability using a nine point Hedonie scale where 9 represents liked extremely and 1, disliked extremely [13].

\subsection{Statistical Analysis}

All determinations were done in triplicates and subjected to Statistical Analysis of Variance (ANOVA) using SPSS version 18 statistical package (SPPS, Inc., USA) to determine variation between means. Duncan Multiple Range Test (DMRT) was used to separate means. Significance variation was accepted at $\mathrm{p}<0.05$.

\section{Results and Discussion}

\subsection{Proximate Composition}

Data in Table 1 depict the proximate composition of dried maize ogi supplemented with levels $(5-20 \%)$ of periwinkle meat flour. The control sample (100\% maize ogi) had high carbohydrate content $(86.66 \%)$, but low crude protein content (7.85\%). The carbohydrate contents of $86.20 \%$ and $82.70 \%$ and protein contents of $8.70 \%$ and $7.00 \%$ were earlier reported by Egounlety and Syariff [1] and Aremu et al. [18], 
respectively for dried maize ogi. The variations in reported values for carbohydrate and protein could be due to differences in maize variety used, growing conditions as well as fermentation conditions. The high carbohydrate and low protein contents of maize ogi suggests that its continuous use as a major weaning food for infants especially in rural communities may lead to protein-energy-malnutrition. Supplementation of maize ogi with levels of periwinkle meat flour ( 5 to $20 \%$ ), resulted in significant $(\mathrm{p}<0.05)$ increased in protein content ranging from $7.85 \%$ for $100 \%$ maize ogi to $14.91 \%$ for $20 \%$ periwinkle meat flour supplemented ogi. The carbohydrate content on the other hand decreased significantly $(\mathrm{p}<0.05)$ from $86.66 \%$ for $100 \%$ maize ogi to $78.75 \%$ for $20 \%$ periwinkle meat flour supplemented ogi. The consistent increased in protein content and decreased in carbohydrate content with increasing levels of periwinkle meat flour supplementation could be attributed to higher protein content and lower carbohydrate content in periwinkle meat flour. Similar observations were reported by Aremu et al. [18], Aminigo and Akingbala [19], Fasasi et al. [20] and
Oluseyi et al. [21] for ogi fortified with groundnut flour, ogi fortified with okra seed meal, maize ogi fortified with tilapia flour and sorghum flour fortified with crayfish, respectively. The crude lipid and fibre contents of the fortified ogi decreased with increasing levels of periwinkle meat flour supplementation. The decrease in crude fibre content with increasing levels of periwinkle meat flour supplementation is not a surprise as animal products contain lower fibre than plants [22]. Conversely, the ash content of the fortified ogi increased significantly $(\mathrm{p}<0.05)$ with increasing levels of periwinkle meat flour supplementation. The higher ash content in the fortified ogi relative to $100 \%$ maize ogi is an indication that periwinkle meat flour addition would contribute to higher mineral content in the ogi. The caloric value of the samples decreased with increasing levels of periwinkle meat flour supplementation. This could be attributed to lower crude lipid and carbohydrate contents of the fortified ogi with increasing levels of periwinkle meat flour supplementation.

Table 1. Proximate composition of dried maize ogi supplemented with periwinkle meat flour (dry wt. basis).

\begin{tabular}{lllllll}
\hline $\begin{array}{l}\text { Blending ration } \\
\text { (\%) MO:PF }\end{array}$ & Crude protein (\%) & Crude Lipid (\%) & Ash (\%) & Crude Fibre (\%) & Carbohydrate (\%) & $\begin{array}{l}\text { Caloric Value } \\
\text { (Kcal/100g) }\end{array}$ \\
\hline $100: 00$ & $7.85^{\mathrm{e}} \pm 0.12$ & $4.05^{\mathrm{a}} \pm 0.04$ & $0.81^{\mathrm{e}} \pm 0.00$ & $0.63^{\mathrm{a}} \pm 0.15$ & $86.66^{\mathrm{a}} \pm 0.04$ & $414.49^{\mathrm{a}} \pm 0.15$ \\
$95: 05$ & $8.96^{\mathrm{d}} \pm 0.09$ & $4.00^{\mathrm{a}} \pm 0.09$ & $1.20^{\mathrm{d}} \pm 0.05$ & $0.61^{\mathrm{a}} \pm 1.12$ & $85.23^{\mathrm{a}} \pm 0.00$ & $412.76^{\mathrm{b}^{\mathrm{a}} \pm 0.08}$ \\
$90: 10$ & $10.75^{\mathrm{c}} \pm 1.13$ & $3.97^{\mathrm{a}} \pm 0.10$ & $1.35^{\mathrm{c}} \pm 0.14$ & $0.60^{\mathrm{a}} \pm 0.09$ & $83.33^{\mathrm{b}} \pm 0.13$ & $412.05^{\mathrm{b}} \pm 0.11$ \\
$85: 15$ & $12.46^{\mathrm{b}} \pm 0.11$ & $3.95^{\mathrm{a}} \pm 0.11$ & $1.64^{\mathrm{b}} \pm 0.09$ & $0.58^{\mathrm{a}} \pm 0.20$ & $81.37^{\mathrm{b}} \pm 0.00$ & $410.87^{\mathrm{c}} \pm 0.06$ \\
$80: 20$ & $14.91^{\mathrm{a}} \pm 1.20$ & $3.91^{\mathrm{a}} \pm 0.20$ & $2.17^{\mathrm{a}} \pm 0.13$ & $0.55^{\mathrm{a}} \pm 1.10$ & $78.75^{\mathrm{c}} \pm 0.11$ & $408.67^{\mathrm{d}} \pm 0.12$ \\
\hline
\end{tabular}

Values are Means \pm SD (Standard deviation) of triplicate determinations. Means on the same column with different superscripts are significantly different at $\mathrm{p}<0.05$.

$\mathrm{MO}=$ Maize ogi; $\mathrm{PF}=$ periwinkle flour.

\subsection{Minerals}

The mineral composition of $100 \%$ maize ogi showed that it had high contents of $\mathrm{K}(141.21 \mathrm{mg} / 100 \mathrm{~g})$ and $\mathrm{Mg}$ $(119.79 \mathrm{mg} / 100 \mathrm{~g})$, but low contents of $\mathrm{Ca}(12.89 \mathrm{mg} / 100 \mathrm{~g})$, $\mathrm{Na} \quad(36.30 \mathrm{mg} / 100 \mathrm{~g}), \quad \mathrm{Fe} \quad(2.57 \mathrm{mg} / 100 \mathrm{~g})$ and $\mathrm{Zn}$ $(0.40 \mathrm{mg} / 100 \mathrm{~g})$. This result is in agreement with the report by Enyisi et al. [23]. The low concentration of $\mathrm{Ca}$ and $\mathrm{Zn}$ in the maize ogi is in agreement with the report by Matilda et al. [24] that cereals are poor in these minerals. Supplementation of maize ogi with $5-20 \%$ levels of periwinkle meat flour resulted in significant decreases $(\mathrm{p}<0.05)$ in $\mathrm{K}$ and $\mathrm{Mg}$ contents ranging from $138.83 \mathrm{mg} / 100 \mathrm{~g}$ and $115.38 \mathrm{mg} / 100 \mathrm{~g}$ in $5 \%$ periwinkle meat flour substituted ogi to $130.86 \mathrm{mg} / 100 \mathrm{~g}$ and $108.34 \mathrm{mg} / 100 \mathrm{~g}$ in $20 \%$ periwinkle meat flour substituted ogi, respectively. These decreases notwithstanding, the fortified ogi sill contained appreciable levels of $\mathrm{K}$ and $\mathrm{Mg}$. High amount of $\mathrm{K}$ has been reported to help in reducing blood pressure [25]. Magnesium is involved in the formation of bone structure in the body [11]. On the other hand, $\mathrm{Ca}, \mathrm{Na}$, $\mathrm{Fe}$ and $\mathrm{Zn}$ contents in the fortified ogi consistently increased with increasing levels of periwinkle meat flour supplementation. The increases ranged from 16.51, 40.09, 3.28 and $0.63 \mathrm{mg} / 100 \mathrm{~g}$ in $5 \%$ periwinkle meat flour supplemented ogi to $28.02,49.75,4.37$ and $1.55 \mathrm{mg} / 100 \mathrm{~g}$ in $20 \%$ periwinkle meat flour supplemented ogi, respectively. The consistent increases in these minerals with increased addition of periwinkle meat flour indicate that periwinkle meat flour had higher content of these minerals than maize ogi. The physiological roles of mineral elements in human diets have been documented [26].

Table 2. Mineral content of dried maize ogi supplemented with periwinkle meat flour (mg/100g).

\begin{tabular}{lllllll}
\hline Blending ration (\%) MO:PF & K & Ca & Na & Mg & Fe & Zn \\
\hline $100: 00$ & $141.21^{\mathrm{a}^{\mathrm{a}} \pm 1.10}$ & $12.89^{\mathrm{e}} \pm 1.21$ & $36.30^{\mathrm{e}} \pm 0.95$ & $119.70^{\mathrm{a}} \pm 0.08$ & $2.57^{\mathrm{c}} \pm 0.11$ & $0.40^{\mathrm{d}} \pm 0.20$ \\
$95: 05$ & $138.83^{\mathrm{b}} \pm 0.09$ & $16.51^{\mathrm{d}} \pm 1.15$ & $40.09^{\mathrm{d}} \pm 1.14$ & $115.38^{\mathrm{b}} \pm 0.12$ & $3.28^{\mathrm{b}} \pm 0.20$ & $0.63^{\mathrm{c}} \pm 0.93$ \\
$90: 10$ & $135.90^{\mathrm{c}} \pm 0.13$ & $19.71^{\mathrm{c}} \pm 0.91$ & $43.83^{\mathrm{c}} \pm 1.20$ & $113.01^{\mathrm{c}} \pm 0.53$ & $3.93^{\mathrm{b}} \pm 0.13$ & $0.94^{\mathrm{b}} \pm 0.11$ \\
$85: 15$ & $133.01^{\mathrm{d}} \pm 0.11$ & $23.64^{\mathrm{b}} \pm 0.78$ & $45.69^{\mathrm{b}} \pm 0.86$ & $110.85^{\mathrm{d}} \pm 0.09$ & $4.16^{\mathrm{a}} \pm 0.13$ & $1.23^{\mathrm{a}} \pm 0.14$ \\
$80: 20$ & $130.86^{\mathrm{e}^{\mathrm{a}} \pm 1.08}$ & $28.02^{\mathrm{a}} \pm 1.10$ & $49.75^{\mathrm{a}} \pm 1.12$ & $108.34^{\mathrm{e}} \pm 0.61$ & $4.37^{\mathrm{a}} \pm 0.10$ & $1.55^{\mathrm{a}} \pm 0.21$ \\
\hline
\end{tabular}

Values are Means \pm SD (Standard deviation) of triplicate determinations. Means on the same column with different superscripts are significantly different at $\mathrm{p}<0.05$.

$\mathrm{MO}=$ Maize ogi; $\mathrm{PF}=$ periwinkle flour. 


\subsection{Functional Properties}

The effect of periwinkle meat flour supplementation on the functional properties of dried maize ogi is presented in Table 3. The bulk density, water absorption and swelling capacities of the fortified ogi decreased with increasing levels of periwinkle meat flour supplementation ranging from $0.60 \mathrm{~g} / \mathrm{cm}^{3}, 0.86 \mathrm{~g} / \mathrm{g}$ and $1.29 \mathrm{ml} / \mathrm{g}$ for $100 \%$ maize ogi to $0.56 \mathrm{~g} / \mathrm{cm}^{3}, 0.82 \mathrm{~g} / \mathrm{g}$ and $1.19 \mathrm{ml} / \mathrm{g}$ for $20 \%$ periwinkle meat flour supplemented ogi, respectively. The observed decreased in bulk density with increase in periwinkle meat flour supplementation could be attributed to decrease in carbohydrate as the level of periwinkle meat flour in the blends increases (Table 1). Similar observations were reported by Fasasi et al. [20] for fermented maize and nile tilapia flour blends and Oluseyi et al. [21] for fermented sorghum and crayfish flour blends. The reduction in bulk density due to periwinkle meat flour supplementation would be an advantage in the formulation of baby foods where high nutrient density to low bulk is desired [27, 28]. This is because the lower the bulk density value, the higher the amount of flour particles that can stay together and thus increasing the energy content that could be derived from such diet [28]. Decrease in bulk density may also help in reduction of packaging and transport cost [29].

Water absorption and swelling capacities are important parameters which ultimately determine sample consistency and are dependent on the compositional structure of the sample [28]. The water absorption capacity obtained in this study for $100 \%$ maize ogi $(0.86 \mathrm{~g} / \mathrm{g})$ was higher than $0.67 \mathrm{~g} / \mathrm{g}$ reported by Alka et al. [30] but lower than $1.12-1.46 \mathrm{~g} / \mathrm{g}$ reported by Beugre et al. [31] for fermented maize flour. The differences in values could be due to differences in growing conditions, varietal differences and fermentation conditions. The decrease in water absorption and swelling capacities with increasing levels of periwinkle meat flour addition could be an advantage because flours with low water absorption and swelling capacities would provide more nutrients - dense complementary food due to reduced swelling capacity [28].

The oil absorption and foaming capacities of the ogi increased consistently with increase in the levels of periwinkle meat flour supplementation ranging from $0.75 \mathrm{~g} / \mathrm{g}$ and $1.96 \%$ for $100 \%$ maize ogi to $0.82 \mathrm{~g} / \mathrm{g}$ and
$6.02 \%$ for $20 \%$ periwinkle meat flour supplemented ogi. The oil absorption capacity obtained in this study was lower than the values $0.88-1.24 \mathrm{~g} / \mathrm{g}$ reported by Beugre et al. [31] for fermented maize flours. This could be due to varietal differences and fermentation conditions. Oil absorption capacity is of great importance since fat acts as flavour retainer and increases the mouth feel of foods [29]. It is exhibited by proteins in the flours which physically bind to fat by capillary attraction [29, 32]. The proteins expose more non-polar amino acids to the fat and enhance hydrophobicity as a result of which flours absorb oil. The consistent increased in oil absorption capacity of the ogi with increasing levels of periwinkle meat flour supplementation could therefore be attributed to increase in protein content in fortified ogi with increase in periwinkle meat flour supplementation (Table 1). The $100 \%$ maize ogi exhibited very poor foaming capacity (1.96\%). Addition of periwinkle meat flour to the maize ogi significantly $(p<0.05)$ increased the foaming capacity of the blends ranging from $2.51 \%$ for $5 \%$ supplemented ogi to $6.02 \%$ for $20 \%$ supplemented ogi blend. This could be attributed to increase protein content in the blends with increasing levels of periwinkle meat flour supplementation. Sathe et al. [17] noted that the ability of the flours to form foam depends on the presence of flexible protein molecules which may decrease the surface tension of water. The least gelation concentration of the $100 \%$ maize ogi flour was $8 \%$. This result is in agreement with the report by Bolaji et al. [29] who also recorded $8 \%$ least gelation concentration for maize ogi. Supplementation of the ogi with periwinkle meat flour above $5 \%$ led to increase in least gelation concentration to $10 \%$. Fasasi et al. [20] however reported that addition of tilapia flour to fermented maize flour improved it gelling ability. Gelling property is a function of the ability of the flour to absorb water and swell [20]. The variation in least gelation concentration could be attributed to the relative ratios of different constituents including proteins, carbohydrates and lipids in the flour samples [20]. The gelation property of the flour provides consistency in food preparation especially semi-solid products [33]. The lower the least gelation concentration value, the better the gelling ability of the flour [32].

Table 3. Functional properties of dried maize ogi supplemented with periwinkle meat flour (dry wt. basis).

\begin{tabular}{lllllll}
\hline $\begin{array}{l}\text { Blending ration }(\%) \\
\text { MO:PF }\end{array}$ & $\begin{array}{l}\text { Bulk Density } \\
\left(\mathbf{g} / \mathbf{c m}^{3}\right)\end{array}$ & WAC $(\mathbf{g} / \mathbf{g})$ & OAC $(\mathbf{g} / \mathbf{g})$ & Swelling Index $(\mathbf{m l} / \mathbf{g})$ & Foaming Capacity (\%) & $\begin{array}{l}\text { Least Gelation } \\
\text { Capacity }(\%)\end{array}$ \\
\hline $100: 00$ & $0.60^{\mathrm{a}} \pm 0.10$ & $0.86^{\mathrm{a}} \pm 0.23$ & $0.75^{\mathrm{b}} \pm 0.14$ & $1.28^{\mathrm{a}} \pm 0.00$ & $1.96^{\mathrm{d}} \pm 0.13$ & $8.00^{\mathrm{a}} \pm 0.02$ \\
$95: 05$ & $0.59^{\mathrm{a}} \pm 0.11$ & $0.85^{\mathrm{a}} \pm 0.15$ & $0.77^{\mathrm{b}} \pm 0.93$ & $1.28^{\mathrm{a}} \pm 0.04$ & $2.51^{\mathrm{c}} \pm 0.10$ & $8.00^{\mathrm{a}} \pm 0.05$ \\
$90: 10$ & $0.58^{\mathrm{a}} \pm 0.09$ & $0.85^{\mathrm{a}} \pm 0.11$ & $0.79^{\mathrm{a}} \pm 1.10$ & $1.26^{\mathrm{a}} \pm 0.08$ & $3.74^{\mathrm{b}} \pm 0.09$ & $10.00^{\mathrm{a}} \pm 0.02$ \\
$85: 15$ & $0.57^{\mathrm{a}} \pm 0.11$ & $0.84^{\mathrm{a}} \pm 0.14$ & $0.81^{\mathrm{a}} \pm 0.15$ & $1.21^{\mathrm{a}} \pm 0.11$ & $4.81^{\mathrm{b}} \pm 0.13$ & $10.00^{\mathrm{a}} \pm 0.10$ \\
$80: 20$ & $0.55^{\mathrm{a}} \pm 0.13$ & $0.82^{\mathrm{b}} \pm 0.09$ & $0.82^{\mathrm{a}} \pm 0.21$ & $1.19^{\mathrm{b}} \pm 0.03$ & $6.02^{\mathrm{a}} \pm 0.11$ & $10.00^{\mathrm{a}} \pm 0.04$ \\
\hline
\end{tabular}

Values are Means \pm SD (Standard deviation) of triplicate determinations. Means on the same column with different superscripts are significantly different at $\mathrm{p}<0.05$.

$\mathrm{MO}=$ Maize ogi $\mathrm{PF}=$ periwinkle flour; $\mathrm{WAC}=$ Water absorption capacity; $\mathrm{OAC}=$ Oil absorption capacity. 


\subsection{Sensory Evaluation}

The mean scores of sensory attributes of prepared ogi gruel are presented in Table 4. The unfortified maize ogi gruel which is the traditional form of consuming ogi had the highest acceptability for all the attributes in terms of appearance, taste, consistency and overall acceptability. There was no significant $(\mathrm{p}>0.05)$ different in the taste of the unfortified and fortified ogi. The appearance, taste, consistency and overall acceptability of ogi fortified with up to $10 \%$ level of periwinkle meat flour did not differ significantly $(\mathrm{p}>0.05)$ from the $100 \%$ maize ogi gruel. The $10 \%$ level of supplementation was therefore judged as being the acceptable limit of periwinkle meat flour supplementation of maize ogi by the panelists.

Table 4. Mean sensory scores for dried maize ogi supplemented with periwinkle meat flour (dry wt. basis).

\begin{tabular}{lllc}
\hline Blending ration (\%) MO:PF & Appearance & Taste & Consistency \\
\hline $100: 00$ & $7.65^{\mathrm{a}} \pm 1.16$ & $6.77^{\mathrm{a}} \pm 1.20$ & $7.59^{\mathrm{a}} \pm 1.53$ \\
$95: 05$ & $7.58^{\mathrm{a}} \pm 1.21$ & $6.73^{\mathrm{a}} \pm 1.93$ & $7.51^{\mathrm{a}} \pm 1.09$ \\
$90: 10$ & $7.44^{\mathrm{a}} \pm 1.10$ & $6.70^{\mathrm{a}} \pm 1.15$ & $7.47^{\mathrm{a}} \pm 1.32$ \\
$85: 15$ & $6.95^{\mathrm{a}} \pm 1.11$ & $6.70^{\mathrm{a}} \pm 1.20$ & $7.00^{\mathrm{a}} \pm 1.16$ \\
$80: 20$ & $6.78^{\mathrm{b}} \pm 1.10$ & $6.68^{\mathrm{b}} \pm 1.14$ & $7.36^{\mathrm{a}} \pm 1.15$ \\
\hline
\end{tabular}

Means on the same column with different superscripts are significantly different at $\mathrm{p}<0.05$.

$\mathrm{MO}=$ Maize ogi; $\mathrm{PF}=$ periwinkle flour.

\section{Conclusion}

The findings of this study indicate that fortifying fermented maize ogi with levels of periwinkle meat flour $(5-$ $20 \%$ ) helped to increase the protein content, some minerals and functional properties of the blends. The crude protein, ash, $\mathrm{Ca}, \mathrm{Na}, \mathrm{Fe}, \mathrm{Zn}$, oil absorption capacity and foaming capacity increased consistently with increasingly levels of periwinkle meat flour substitution. On the other hand, crude lipid, crude fibre, carbohydrate, caloric value, $\mathrm{K}, \mathrm{Mg}$, bulk density, water absorption capacity and swelling capacity decreased with increasing levels of periwinkle meat flour substitution. Reduction in carbohydrate and increase in protein content with addition of periwinkle meat flour would help to address the problem of protein-energy-malnutrition associated with the consumption of unfortified ogi. The result of sensory evaluation revealed that gruel prepared from ogi fortified with up to $10 \%$ periwinkle meat flour did not differ significantly $(\mathrm{p}>0.05)$ from the $100 \%$ maize ogi gruel in all the parameters evaluated.

\section{References}

[1] Egounlety, N. and Syarief, R. Study on the supplementation of ogi with tempe. Nig. Food J., 1992, 10: 92-102.

[2] Olusanya, J. O. Essentials of food and nutrition. 2008, Appex Books Limited, Lagos, Nigeria, pp. 271-279.

[3] Adewale, B., Daniel, A. and Aremu, C. O. The nutritional potential and possibilities in African jam bean for Africans. Int. J. Agric. Sc., 2013, 3(1): 8-19.

[4] Banigo, E. B. and Muller, H. G. Manufacture of ogi (A Nigerian fermented cereal porridge): Comparative evaluation of corn, sorghum and millet. Canadian Inst. Food Tech. J., 1992, 5: 217-221.
[5] Akingbala, J. O., Rooney, L. W. and Faubion, J. M. A laboratory procedure for the preparation of ogi, a Nigerian fermented food. J. Food Sci., 1981, 46: 1523-1526.

[6] Oyewole, O. B. Lactic fermented foods in Africa and their benefits. Food Contr., 1997, 8: 289-297.

[7] Banigo, E. B. and Akpapunam, M. A. Physico-chemical and nutritional evaluation of protein enriched fermented maize flour. Nig. Food J., 1987, 5:30-36.

[8] Akinrele, I. A. and Edwards, C. C. A. An assessment of the nutritive value of a maize -soya mixture, "soy-ogi", as a weaning food in Nigeria. British. J. Nutr., 1971, 26(2): 177185 .

[9] Okeiyi, L. C. and Futrell, M. F. Evaluation of protein quality of formulation of sorghum grain flour and legume seeds. Nutr. Report Intern., 1983, 28(3): 451-461.

[10] Adebayo-Tayo, B. C. and Ogunjobi, A. A. Comparative effects of oven drying and sun drying on the microbial, proximate, nutrient and mineral composition of Tympanotonus spp (periwinkle) and Crassatrea spp (Oyster). Elect. J. Environ. Agric. Food Chem., 2008, 7(4): 856-861.

[11] Ogunbenle, O. and Omowole, C. Use of sea shells and marine resources. J. Environ. Sci., 2012, 11: 27-34.

[12] AOAC, Official Methods of Analysis ( $17^{\text {th }}$ edn.). Association of official analytical chemists, 2000, Washington D. C., USA.

[13] Ihekoronye, A. I. and Ngoddy, P. O. (eds.). Integrated Food Science and Technology for the Tropics. 1985, MacMillan Edu. Publishers, London, pp. 283-285.

[14] Osborne, D. R. and Voogt, P. (eds.). The analysis of nutrients in foods. 1978, Academic Press, New York, p. 239.

[15] Okezie, B. O. and Bello, A. B. Physico-chemical and functional properties of winged bean flour and isolate compared with soy isolates. J. Food Sci., 1988, 53(2): 450-454.

[16] Abbey, B. W. and Ibeh, G. O. Functional properties of raw and heat processed cowpea (Vigna unguiculata) flour. J. Food Sci., 1988, 53(6): 1178-1188. 
[17] Sathe, S. K., Desphande, S. S. and Salunkhe, D. K. Functional properties of lupin seed (Lupinus mutabilis) protein and protein concentrate. J. Food Sci., 1982, 47: 491-497.

[18] Aremu, M. O., Osinfade, B. G., Basu, S. K. and Ablaku, B. E. Development and nutritional quality evaluation of kerstings groundnut - ogi for African weaning diet. Amer. J. Food Technol., 2011, 6: 1021-1033.

[19] Aminigo, E. R. and Akingbala, J. O. Nutritive composition and sensory properties of ogi fortified with okra seed meal. J. Appl. Sci. Environ. Magt., 2004, 8(2): 23-28.

[20] Fasasi, O. S. Adeyemi, I. A. and Fabenro, O. A. Functinal and pasting characteristics of fermented maize and nile tilapia (Oreochromis niloticus) flour diet. Pak. J. Nutr., 2007, 6(4): 304-309.

[21] Oluseyi, A. K., Oluwafunmilalo, A., Oluwasegun, S. T., Abimbola, A. A., Oluwatoyin, A. C. and Olubusola, O. Dietary fortification of sorghuin using crayfish (Paranephrops planifrons) as supplements in infancy. Food Sci. Quality Mangt.. 2013, 15: 1-9.

[22] Jike-Wai, O. and Deekae, S. N. Chemical and mineral compositions of commercially important shellfish in Rivers State, Nigeria. Amer-Euras. J. Agric. Environ., 2011, 10(5): 752-754.

[23] Enyisi, I. S., Umoh, V. J., Whong, C. M. Z., Abdullahi, I. O. and Alabi, O. Chemical and nutritional value of maize and maize products obtained from selected markets in Kaduna State, Nigeria. Afr. J. Food Sci. Technol., 2014, 5(4): 100-104.

[24] Matilda, A., Rune, N., Oyvind, L. and Einar, L. Effect of processing (sprouting and/or fermentation) on sorghum and maize I: Proximate composition, mineral and fatty acids. Food Chem., 1993, 46: 351-353.

[25] Rohantra, G. S., Gelrorth, J. A., Leine, S. O., Viras, M. A. and Lorenz, K. J. Nutritional profile of some edible plants from Mexico. J. Food Comp. Anal., 1998, 11: 298-304.
[26] Grosvernor, M. B. and Smolin, L. A. (eds.). Nutrition: from science to life. 2002, Harcourt College Publishers, New York, USA, pp. 288-371.

[27] Iwe, M. O. and Onadipe, O. O. Effect of addition of extruded full-fat soy flour into sweet potato flour on functional properties of the mixture. J. Sustain. Agric. Environ., 2001, 3; 109-117.

[28] Ayo-Omogie, H. and Ogunsakin, R. Assessment of chemical, rheological and sensory properties of fermented maize Cardaba banana complementary food. Food Nutr. Sci., 2013, 4(8): 844-850.

[29] Bolaji, O. T., Oyewo, A. O. and Adepoju, P. A. Soaking and drying effect on the functional properties of ogi produced from selected maize varieties. Amer. J. Food Sci. Technol., 2014, 2(5): 150-157.

[30] Alka, S., Neelam, Y. and Shruti, S. Effect of fermentation on physico-chemical properties and in vitro starch and protein digestibility of selected cereals. Int. J. Agric. Food Sci., 2012, 2(3): 66-70

[31] Beugre, G. A. M., Yapo, B. M., Blei, S. H. and Gnakri, D. Effect of fermentation time on the physico-chemical properties of maize flour. Int. J. Res. Studies Biosci., 2014, 2(8): 30-38.

[32] Shad, M. A., Nawaz, H., Noor, M., Ahmad, H. B., Hussain, M. and Choudhry, M. A. Functional properties of maize flour and its blends with wheat flour: Optimization of preparation conditions by response surface methodology. Pak. J. Bot,. 2013, 45(6): 2027-2035.

[33] Bhat, R. and Srithsr, K. R. Nutritional quality of electron beam irradiated lotus (Nelumbo nucifera). Food Chem., 2008, 107: $174-184$ 